\title{
Rereading 'A Rose for Emily' from the Perspective of Wolfgang Iser's Reader Response Theory
}

\author{
Sura M. Khrais \\ Al-Balqa Applied University, Jordan
}

Received: 25-04-2017

Accepted: 17-06-2017

Published: 31-07-2017

doi:10.7575/aiac.ijclts.v.5n.3p.28

URL: http://dx.doi.org/10.7575/aiac.ijclts.v.5n.3p.28

\begin{abstract}
The aim of this paper is to examine Iser's 'reader response' theory with special focus on Iser's concept of 'dynamic reading' and 'blanks' as major narrative devices. The researcher will discuss how blanks or gaps function, through applying Iser's theory on William Faulkner's "A Rose for Emily". She will discuss how gaps in characters and events engage the reader in a dynamic process of reading which leads to revealing the text's meaning. This paper is an application of text-reader interaction which, as Iser states, generates meaning. It is worth mentioning here that Iser views meaning as an effect to be experienced rather than an object to be defined. It is here where Iser's contribution to the world of criticism becomes clear. He redirects focus from the text as an object to the subjectivity of the reader. Keywords: Iser's Reader Response Theory, Dynamic Reading, Blanks, Text-Reader Interaction

\section{Introduction}

Wolfgang Iser is a major theorist from 1970's German 'Constance' school which has set the course for much of social and communication theories in the contemporary German intellectual arena. Iser spotlights the aesthetic value of the reading process. According to him, there are two poles involved in the reader's experience of interpreting the text: the artistic pole which is the text that is created by the author and the aesthetic pole which is the reader's revelation of meaning (Iser, 2010, 1524). Somewhere between the two poles is the literary work which readers create by reading or realising the text. Iser states that the text and the reader are not strictly connected, thus separating the text and the reader. He states that it is "the imbalance between text and reader" which makes communication possible and advances it at the same time (Iser, 2010, 1526). Thus interaction between text and reader is generated again. This interaction is what Iser refers to as the aesthetic response which is the emblem of reception theory. Aesthetic response stimulates the reader's imagination which gives life to the intended effects (Iser, 2000, 311). It is exactly here where Iser's theory of gaps or blanks emerges.
\end{abstract}

\section{Discussion}

Iser's argument that reading is not passive is the major element in his theory of reading. Reading is a dynamic, i.e., readers keep revising and reviewing constantly what they have read whilst being simultaneously influenced by past and present revelations. Gaps in the literary text, Iser confirms, are the main reason behind this constant process of revising the text. The reader's response to these gaps is nothing but her perception of the text. However, this understanding may change through rereading, revising and reviewing the text. As a result, new concepts, different revelations and critical points of view appear on the surface. This notion of Iser supports his other thought that textual criticism is useless because there is no one interpretation of a text (Iser, 2010, 1526). It also leads to iser's idea of the wandering viewpoint. Iser suggests that as the reader's mind starts reconsidering what she has read, things become more and less significant. The reader's wandering point of view is now able to identify previously unrecognised blanks and make connections within the text. Looking back, the reader now realises new meanings and different conclusions. This sheds light on another aspect in Iser's theory. Iser affirms that once a gap is identified as a gap, it ceases to be a gap. The reader manages to recognise overt gaps and works hard to spot covert gaps. Usually, the dynamic process of reading the text which motivates us to look back at earlier conclusions and reconsider previous meanings enables the reader to identify covert gaps. Nevertheless, there are gaps which leave the reader restless. They unnerve her because they remain unfilled no matter how hard the reader tries. This is a problematic issue in Iser's theory. For instance, the unnamed narrator of Faulkner's story remains a mystery to readers. Bits of information at the beginning of narrative lead us to believe that he is a member of Miss Emily's town. However, the narrator is never given a name or clearly identified. The role of gaps in understanding the text is crucial in Iser's theory. Through blanks, communication between reader and text develops. The importance of gaps stems from Iser's notion that they provide a variety of textual perspectives, leaving the text to the reader to decipher. While these blanks are open for interpretation, they also have a power over the reader. In other words, gaps control the reader. Unfortunately, Iser never explains to what extent the blank can control a reader (Duckworth, 339). In fact, this grey area is generated by Iser's assertion that the text and the reader do not share a common code. Furthermore, the reader can, but also chooses not to perceive the text the way other readers view it. This gap in communication (between reader and text; between reader and other readers) allows the reader to shape his own views. 
In The Act of Reading, Iser states that it is the gap that guides the reader (Iser, 2010, 1527). Nonetheless, Iser does not suggest that an objective meaning is hidden within the text. Rather literature produces effects of meaning for the reader in the virtual space created between the reader and the text. The text leaves great part unexplained to the reader, whether as gaps in the narrative or as structural limits of the text's representation of the world. This indeterminacy 'implies' the reader (Iser's concept of the 'Implied Reader' 1974) and implores her to participate in synthesizing and living events of meaning throughout the process of reading. Like Ingarden, Iser regards the text as a skeleton of schematized aspects that must be actualized or concretized by the reader.

According to Iser, fiction proposes alternate worlds created within the virtual reality of the text's meaning. That is to say, in literature the actual and the possible can exist simultaneously. "Consequently, literature takes on greater human function of imagining beyond the given constraints of experience... [indeed] Iser has explored how literature functions in the human experience [and raises] the largest questions about what it means to be human" (Albertson, 2000). Now, let us consider the following two questions: How are blanks generated? In her review of Iser's reception theory, Yanling Shi (2013) discusses how narrative generates gaps. When the story line suddenly breaks off and continues from another perspective or in an unexpected direction, the result is a blank which the reader completes in an attempt to connect the dispersed segments (984). We will see how the following segments: the smell of Miss Emily's house, arsenic, and disappearance of Homer, create a gap in narration until they are connected by virtue of the closing scene. Why do readers fill in gaps? Iser confirms that the reader is always after a clear unified sense of the text. He aims at achieving consistency by joining contradictory parts of plot through his imagination. Unity and consistency of the text is the result of filling in blanks. These two purposes do not lie within the text, rather they exist somewhere between the text and the consciousness of the reader.

This paper will show how blanks call the reader to action and lead her to conclusions about the text's meaning. We will see how the gaps in "A Rose for Emily", gaps in characters and events, engage the reader and prepare her for action. As a reader, I will try to connect various segments of the text to complete the gaps and join together unconnected segments. Two important questions are to be answered in this study: To what extent can the reader imagine beyond the given experience and to what extent is this process of reading useful?

Now, let us look closely at the opening sentence and our responses to it. While the sentence provides readers with clues to the attitude of townspeople toward Miss Emily, it introduces many gaps about Miss Emily's identity and isolation: "When Miss Emily Grierson died, our whole town went to her funeral: the men through a sort of respectful affection for a fallen monument, the women mostly out of curiosity to see the inside of her house, which no one save an old manservant - a combined gardener and cook — had seen in at least ten years" (119). Besides informing us that Miss Emily has not been visited in ten years, the sentence tells us that men and women come to the funeral out of respect for an extinct institution and out of curiosity. They do not come out of grief to mourn the death of a beloved member of Jefferson Town. The lines raise the readers' curiosity about Miss Emily's identity. Obviously she is a pillar of the community; a fact that is stressed only two paragraphs later: "Alive, Miss Emily had been a tradition, a duty, and a care; a sort of hereditary obligation upon the town..." (119). However, the reason for her ten years of isolation remain a clear gap until we, readers, manage to join together unconnected segments and fill in gaps.

As readers, we wonder whether Miss Emily's isolation is self-imposed or some kind of social punishment? In Part I, the narrator tells us that "no visitor had passed since she ceased giving china-painting lessons eight or ten years earlier" (120). Only in Part IV do we come to know that Miss Emily was forty when she gave those lessons, that her profession lasted for "a period of six or seven years" and that her front door remained closed save for her students of china-painting (124). Her servant went in and out with the market basket, yet the front door remained closed for years. People of the town managed to have glimpses of her "at a window for a moment"(124). Obviously, Miss Emily chooses to shut herself in as she did for years after her father's death. Furthermore, Miss Emily's isolation is associated with the disappearance of Homer Barron introduced to readers early in Part I (120). "[A]fter her sweetheart went away, people hardly saw her at all" (Part II, 121). Such relationship remains a gap until we come closer to the closing scene.

Our reading of the significance of events is modified as we move from one page to another. Early in Part I, we come to know that after her father's death, Colonel Sartoris, the mayor, has remitted Miss Emily's taxes. It seems to be a charitable action which has dated "from the death of her father on into perpetuity" (119). This reading sounds logical especially that Miss Emily was "a duty and a care" looked after by the earlier generation; her father's friends. However, our perception of this part of the story is immediately modified as we read in the following paragraph that the newer generation does not recognise such favour and decides that Miss Emily must pay her taxes. For them she is no more than a citizen, so they send her an impersonal tax notice, a formal letter, an offer from the mayor to meet to discuss the matter, and finally a deputation. When the two generations are juxtaposed, readers are tempted to read the Colonel's act as an attempt to protect Miss Emily's class as she represented ruined aristocracy. It is an act of maintaining the rigid class order than an expression of respect and gratitude for her dead father. The new generation does not recognise Miss Emily's class, consequently, she is not granted any special treatment.

We, readers, modify our expectations during reading because the text changes (Iser, 1974). For instance, the earlier description of Miss Emily's attraction to Homer (Part III) suggests that our heroine has finally found a compensation in what might develop into a love story. However, one sentence about Homer, "He preferred boys" (122), which reveals an unexpected meaning, motivates the reader to become an active participant in the reading process by allowing him to imagine the following incidents. The suggested homosexuality of Emily's so-called lover stimulates the reader to expect failure of the relationship and perhaps Miss Emily's second breakdown. She suffered an earlier breakdown after her 
father's death. This is the kind of expectation rooted in familiarity. The virtual space which the text has created for the reader's imagination allows such anticipation. The author has set guidelines for the reader (Homer disappears, townspeople don't see the couple together anymore), but it is the reader who fills in the blanks by connecting various segments. In this sense, Iser views a piece of literature as the sum of the text written by the author and the sum of the text that is not there, i.e., created by the reader's imagination (Iser, 1974). Nevertheless, narrative defeats our familiar expectations creating for the reader something unfamiliar. Miss Emily poisons Homer; at least we are motivated to believe so through a causal relation of arsenic, the disappearance of Homer, and the smell. Despite the fact that these three clues are introduced to readers in the story in a reverse order, the smell is mentioned in Part II, the poison in Part III, and Homer's disappearance in Part IV, the reader manages to create connections and rearrange details in the correct chronological order. Eventually, Miss Emily keeps Homer, literally, next to her "rotted beneath what was left of the nightshirt" (125). Consequently, the reader is forced to review his earlier preconceptions.

Another example which shows how readers' expectations change all the time is when women in Jefferson have come to believe that Miss Emily is a fallen woman (Part III, 124); that she has become a "a disgrace to the town and a bad example to the young people" (Part IV, 126). Nevertheless, Miss Emily never behaves as a fallen woman in the remaining part of the story. Readers now can make their own judgement, defend Miss Emily and sympathize with her after they come to learn in the closing scene that she dies in pitiable circumstances, alone, solitary, and neglected. A further example is when we and townspeople are made to believe that Miss Emily is going to kill herself after Homer deserted her, people have begun to say "Poor Emily" (122), and she bought the arsenic. Townspeople justify the awaited suicide as an act of revenge for "her dignity as the last Grierson" (123). However, like them our expectations are never fulfilled. The outcome of narrative is shocking for both Jefferson Town and for readers. Miss Emily never kills herself. She kills Homer and lives next to his body until she falls ill in a house filled with dust and shadows and dies at seventy-four (124).

The last scene in the story defeats readers' expectations. It is the climax of narration. It resolves mysteries about the smell, arsenic, and Homer's disappearance. Nevertheless, it sheds light on new mysteries and further gaps. We learn that "[t]he man [Homer] himself lay in bed" and that the body "had once lain in the attitude of an embrace" (125). In addition, we are told that in the second pillow there is "an indentation of a head...[and] a long strand of iron-gray hair" of Emily's(Part V, 125). Many questions arise here. Have Emily and Homer lived together secretly for many years? Has the relationship deteriorated for some reason and he threatened to desert her? Has Emily been sleeping with a dead body and, if the answer is yes, for how long has this sick relationship lasted? A few critics have attempted different readings of the closing scene which reflect Iser's idea that there is no one correct reading to a literary text. For example, Johnson (1948) argues that to live with death is Miss Emily's punishment for resisting the flux of Time symbolised by the new generation. Allen (1960) thinks that Emily takes Homer in defiance as a father-substitute, then kills him to ensure possession when he threatens to leave her (60). It is important in this context to remind ourselves that the threat of desertion never materialises verbally in narrative as we never see Homer confronting Emily; nevertheless, it remains for the townspeople and for readers to speculate about. Howell (1966), on the other hand, argues that Emily cannot kill Homer from a petty motive as revenge. Therefore, the murder is actually a victory of the spirit over the body. Convinced that the affair is immoral, she kills Homer and keeps the body in an act of expiation (13-15). Truly, the last scene remains one among many gaps which are left unresolved. Despite readers' different efforts to decipher the meaning of the text, thus creating the aesthetic pole of the text, the floor is still open for further interpretations.

A further example of the reader's ability to modify earlier perceptions, thus wandering between past and present meanings, is the readers' understanding of Miss Emily's ghostly appearance. Part I raises the readers' doubts about Miss Emily's ghostly appearance: "Her skeleton was small and spare; perhaps that was why what would have been merely plumpness in another was obesity in her" (120) and she "looked bloated, like a body long submerged in motionless water" (120). In other words, she balloons into a drowned corpse. The question is: How come that an heir of aristocracy degenerates into such hideous corpse-like woman? How are we supposed to respond to this description? Terry Heller suggests that the story hints that we may be in Gothic Romance and Miss Emily is a Gothic heroine. The house itself reminds us of Gothic Romance. It is tomblike, dusty, dark, and damp, with a stairway that mountains into shadow (Heller). However, readers will feel more comfortable with the creepy atmosphere created by the description of the house and that of Miss Emily's frightful appearance as events develop. Our acceptance of such details develops thanks to the dynamic process of reading. We come to know in Part V that the upstairs bridal chamber becomes Homer's grave while Miss Emily dies in one of the downstairs bedrooms. A house "filled with dust and shadow" becomes more or less a graveyard (Part V, 125). Not only has Miss Emily become an old woman with iron-grey hair, and Homer or "what was left of him" rotted beneath what was left of the nightshirt (Part V, 125), but they have also decayed as the dusty smelly house. Only in the closing scene that we come to realise the ugly symmetry between the two characters on one hand, and the setting on the other hand.

On the other hand, many mysteries or indeterminacies in "A Rose for Emily" remain unresolved. They leave us restless. For example, townspeople think that Homer Barron is going to marry Miss Emily they see them together on Sunday afternoons driving in the yellow-wheeled buggy (123). Soon, they discover that Homer likes men as he "[drinks ] with the younger men in the Elk's Club - that he was not a marrying type" (Part IV, 123). Yet they say she will "persuade him" (123), but we never know if she does. We know that Barron is back in town. "A neighbour saw the Negro man admit him at the kitchen door at dusk one evening" (124). However, that was the last time townspeople saw him. Has Miss Emily been able to convince him that's why he returned to Jefferson? Has she failed to seduce him into marriage, so she kills him? What has really happened between Emily and Homer? Has the relation developed to a 
promise of marriage that Miss Emily buys "a man's toilet set in silver, with letters H. B. on each piece", yet her lover never keeps his promise? (124). The fact that many questions are left unanswered deepens our suspicion of the truth about what has happened to Homer.

\section{Conclusion}

Iser's reader response theory provides readers with tools to better understand the text and how the reading process works. In reading we discover not only a larger space where we employ our imagination for a better revelation of meaning, but also a dynamic process of perception which negates, confirms, or modifies previous concepts. Thus, reading is fun! Iser's theory motivates us to enjoy our ability to be equally creative.

\section{References}

Albertson, D. (2000). Stanford Presidential Lectures in the Humanities and Arts. https://prelecture.stanford.edu/lectures/ise

Allen, C. A. (1960). "William Faulkner: Comedy and the Purpose of Humor." Arizona Quarterly 16, 59-60.

Duckworth, A. M. (1979). "The Act of Reading: A Theory of Aesthetic Response." Nineteenth-century Fiction 34, (3): 337-343.

Faulkner, W., Gwynn, F. and Blotner, J. (1959). Faulkner in the University: Class Conferences at the University of Virginia, 1957-1958. Charlottesville: Univ. of Virginia Press.

Faulkner, W. (1950). The Collected Stories. New York: Random House, Inc. 119-125.

Heller, T. (1972). "The Telltale Hair: A Critical Study of William Faulkner's A Rose for Emily." Arizona Quarterly 28 : 83-90.

Howell, E. (1966). "A Note on Faulkner's Emily as a Tragic Heroine." Serif, 2: 13-15.

Iser, W. (2010). "Interaction between Text and Reader." In The Norton Anthology of Theory and Criticism, edited by Peter Simon, 1524-32. United States: Norton and Company, Inc.

Iser, W. (2000). "Do I write for an Audience?" PMLA, 115: 3 (May), 310-314.

Iser, W. (1974). The Implied Reader: Patterns of Communication in Prose fiction from Bunyan to Becket. Baltimore and London: The John Hopkins University Press.

Johnson, C. W. M. (1948). "Faulkner's 'A Rose for Emily'." Explicator, 6: item 45.

Shi, Y. (2013). "Review of Wolfgang Iser and His Reception Theory."Theory and Practice in Language Studies, 3(6), 982-986. 